\title{
Pengembangan E-Modul Tema Ekosistem Kelas V SDN 2 Sindangsari Leuwigoong
}

\author{
Herni Hernayati ${ }^{1}$, Rini Atikah ${ }^{2}$, Rani Titik Prihatin ${ }^{3}$, Jajang Misbah ${ }^{4}$ \\ Institut Pendidikan Indonesia \\ Email: herni.hernayati@gmail.com
}

\begin{abstract}
Learning at SDN 2 Sindangsari is currently not being carried out face-to-face, due to the spread of the C 19 epidemic, besides the limited human resources and available media. Therefore, teachers are required to be able to create innovative learning models. This study aims to: (1) develop learning media in the form of teaching materials in the form of electronic modules using the Sigil software application for fifth grade students of SD Negeri 2 Sindangsari, Leuwigoong District. (2) Testing the feasibility of learning products. The method in this study using the Research and Development (R\&D) method is a research and development method used to produce certain products, and to test the effectiveness of these products, it can mean new products or modify existing products that adapt the ADDIE development model (Analysis, Design, Development, Implementation, Evaluation). The resulting data shows that the Sigil software-based electronic module developed can be used as teaching material in the learning process. For this reason, e-Modul is able to help learning in schools as a solution.
\end{abstract}

Keywords: Development, E-Modul.

Abstrak. Pembelajaran di SDN 2 Sindangsari saat ini tidak dilaksanakan secara tatap muka,karena menyebarnya wabah C 19, selain itu keterbatasan SDM dan media yang tersedia. Oleh karena itu, guru dituntut untuk bisa menciptakan model pembelajaran yang inovatif. Penelitian ini bertujuan untuk : (1) mengembangkan media pembelajaran berupa bahan ajar dalam bentuk modul elektronik dengan menggunakan aplikasi software Sigil untuk siswa kelas V Sekolah Dasar Negeri 2 Sindangsari Kec.Leuwigoong. (2) Menguji kelayakan produk pembelajarannya. Metode dalam penelitian ini menggunakan metode Research and Development (R\&D) adalah metode penelitian dan pengembangan yang digunakan untuk menghasilkan produk tertentu,dan menguji keefektifan produk tersebut, dapat berarti produk baru atau memodifikasi produk yang sudah ada yang mengadaptasi model pengembangan ADDIE (Analysis, Design, Development, Implementation, Evaluation). Dari data yang dihasilkan menunjukkan bahwa modul elektronik berbasis software Sigil yang dikembangkan dapat digunakan sebagai bahan ajar dalam proses pembelajaran. Untuk itu e-Modul mampu membantu pembelajaran di sekolah sebagai solusi.

\section{Kata Kunci: Pengembangan, E-Modul}

\section{PENDAHULUAN}

Pendidikan memiliki peran yang sangat penting untuk kemajuan suatu negara, karena dengan adanya pendidikan dapat meningkatkan kualitas sumber daya manusia. Suatu bangsa yang sudah maju sudah pasti memiliki sumber daya manusia yang berkualitas. Salah satunya ditandai dengan pendidikan yang sudah mampu membentuk watak setiap individu menjadi lebih baik. Sesuai dengan fungsi pendidikan nasional yang tercantum dalam UU nomor 20 Tahun 2003 Pasal 3 tentang Sisdiknas yaitu pendidikan berfungsi untuk mengembangkan kemampuan dan membentuk watak serta peradaban bangsa yang bermartabat dalam rangka mencerdaskan kehidupan bangsa (Sukirno and Syamsuriyanti 2018).

Istilah pendidikan pada dasarnya adalah proses komunikasi dan informasi dari pendidik terhadap peserta didik yang berisi informasiinformasi pendidikan, yang terdiri dari pendidik sebagai fasilitator dan sebagai bagian dari sumber informasi, peserta didik sebagai orang yang belajar, serta media sebagai sarana 
penyajian ide, gagasan, dan materi pendidikan (Darmawan 2014). Pendidikan yang berkualitas tidak lepas dari seorang guru yang mampu memanfaatkan teknologi dalam proses pembelajaran. Seiring dengan kemajuan teknologi, guru juga dituntut dapat meningkatkan kompetensi yang dimilikinya dalam proses pembelajaran agar tujuan pembelajaran dapat tercapai dengan baik. Guru mempunyai peranan yang sangat penting dalam kegiatan belajar. Oleh karena itu, guru harus merancang kegiatan pembelajaran dengan sebaik mungkin agar pembelajaran menjadi bermakna. Guru berperan penting dalam proses pembelajaran, karna memiliki peran yang sangat besar.

Berbagai macam jenis komponen atau alat dalam lingkungan siswa yang dapat merangsang siswa untuk belajar dpat tergolong sebagai media pembelajaran. Media dapat berupa sarana yang mengkomunikasikan pengetahuan dan keterampilan, jika media yang digunakan tepat maka akan membantu efektivitas penyampaian bahan ajar yang dilakukan oleh guru.

Berdasarkan hasil informasi di SDN 2 Sindangsari Leuwigoong, penulis memproleh informasi bahwa sumber belajar yang digunakan saat ini pada pembelajaran saat ini adalah berupa buku tema dalam jumlah yang terbatas.

Kondisi saat ini dimana semua tempat mengalami peristiwa adanya penyebaran wabah penyakit covid 19, peran guru sangat diharapkan dapat menjalankan proses pembelajaran dengan semaksimal mungkin. Interaksi dalam pembelajaran meliputi interaksi guru dengan murid, interaksi murid dengan murid lainnya, interaksi murid dengan bahan ajar diharapkan dapat terjadi dengan baik. Interaksi yang ada dalam pembelajaran tersebut diharapkan dapat dilakukan juga secara maksimal dalam kondisi yang tidak kondusif seperti saat ini. Keberadaan bahan ajar yang lengkap menjadi suatu kebutuhan apalagi saat ini pembelajaran hampir kebanyakan dilakukan secara daring.

Sedikitnya terdapat dua kendala dalam pembelajaran tematik di kelas V SDN 2 Sindangsari yang penulis dapatkan yaitu terbatasnya sumber belajar dan kondisi saat ini dengan menyebarnya wabah yang mengharuskan pembelajaran dilaksanakan secara daring.
Oleh karena itu, interaksi siswa dengan bahan ajar berupa modul elektronik (e-modul) menjadi satu hal penting untuk kondisi saat ini. Berdasarkan hal tersebut maka perlu dilakukan penelitian yang berjudul "Pengembangan EModul Tema Ekosistem Kelas V SDN 2 Sindangsari Leuwigoong".

\section{Rumusan masalah}

Berdasarkan latar belakang di atas maka dapat disusun rumusan masalah untuk penelitian ini adalah:

1. Bagaimana mengembangkan media pembelajaran berupa bahan ajar dalam bentuk modul elektronik tema ekosistem dengan menggunakan aplikasi software Sigil untuk siswa kelas V Sekolah Dasar Negeri 2 Sindangsari Kecamatan Leuwigoong?

2. Bagaimana kelayakan produk modul elektronik tema ekosistem dengan menggunakan aplikasi software Sigil untuk siswa kelas V Sekolah Dasar Negeri 2 Sindangsari Kecamatan Leuwigoong?

\section{Tujuan Penelitian}

Berdasarkan rumusan masalah yang telah dirumuskan di atas maka dapat disusun tujuan penelitian sebagai berikut :

1. Untuk mengembangkan media pembelajaran berupa bahan ajar dalam bentuk modul elektronik tema ekosistem dengan menggunakan aplikasi software Sigil untuk siswa kelas V Sekolah Dasar Negeri 2 Sindangsari Kecamatan Leuwigoong.

2. Untuk menguji kelayakan produk modul elektronik tema ekosistem dengan menggunakan aplikasi software Sigil untuk siswa kelas V Sekolah Dasar Negeri 2 Sindangsari Kecamatan Leuwigoong.

\section{KAJIAN PUSTAKA}

Pembelajaran adalah suatu proses yang dilakukan oleh individu untuk memperoleh suatu perubahan perilaku yang baru secara keseluruhan, sebagai hasil dari pengalaman individu itu sendiri dalam interaksi dengan lingkungannya (Surya, 2004) Pembelajaran merupakan suatu sistem, yang terdiri atas berbagai komponen yng saling berhubungan satu dengan yang lain. Komponen tersebut meliputi : tujuan, materi, metode dan evaluasi. 
Keempat komponen pembelajaran tersebut harus diperhatikan oleh guru dalam memilih dan menentukan model pembelajaran apa yang akan digunakan dalam kegiatan pembelajaran. Model pembelajaran biasanya disusun berdasarkan berbagai prinsip atau teori sebagai pijakan dalam pengembangannya. Joyce dan Weil (dalam (Sagala. S 2008) yaitu Model pembelajaran adalah suatu deskripsi dari lingkungan belajar yang menggembarkan perencanaan kurikulum, kursus-kursus, desai unit-unit pelajaran dan pembelajaran, perlengkapan belajar, buku-buku kerja. Program multimedia. Dan bantuan belajar melalui program komputer.

Teknologi Pembelajaran tumbuh dari praktek pendidikan dan gerakan komunikasi audio visual. Teknologi Pembelajaran semula dilihat sebagai teknologi peralatan, yang berkaitan dengan penggunaan peralatan, media dan sarana untuk mencapai tujuan pendidikan atau dengan kata lain mengajar dengan alat bantu audio-visual. Teknologi Pembelajaran merupakan gabungan dari tiga aliran yang saling berkepentingan yaitu media pendidikan, psikologi pembelajaran dan pendekatan sistem dalam pendidikan.

\begin{tabular}{|c|c|c|}
\hline & $\mathrm{Me}$ & AECT, \\
\hline
\end{tabular}
"komunikasi audio-visual adalah cabang dari teori dan praktek pendidikan yang terutama berkepentingan dengan mendesain dan menggunakan pesan guna mengendalikan proses belajar, mencakup kegiatan : a) mempelajari kelemahan dan kelebihan suatu pesan dalam proses belajar ; b) penstrukturan dan sistematisasi oleh orang maupun instrumen dalam lingkungan pendidikan, meliputi : perencanaan, produksi, pemilihan, manajemen dan pemanfaatan dari komponen maupun keseluruhan sistem pembelajaran. Tujuan praktisnya adalah pemnafaatan tiap metode dan medium komunikasi secara efektif untuk membantu pengembangan potensi pembelajar secara maksimal". Sedangkan menurut CIT, dalam(Warsita 2008) "Dalam pengertian lebih umum, Teknologi Pembelajaran diartikan sebagai media yang lahir sebagai akibat revolusi komunikasi yang dapat digunakan untuk keperluan pembelajaran di samping guru, buku teks, dan papan tulis bagian yang membentuk teknologi pembelajaran adalah televisi, film, OHP, komputer dan bagian perangkat keras maupun lunak lainnya".

Sumber belajar meliputi alat, materi ajar, perangkat belajar dan sumberdaya manusia yang terlibat dalam proses belajar sehinggga terjadi facilitating learning and improving performance. Bahan ajar akan menjadi bermakna jika dikembangkan melalui suatu rancangan yang memungkinkan peserta didik dapat memanfaatkannya dan menggunakannya secara efektif sesuai karakteristik peserta didik dengan tepat.

Bahan ajar adalah salah satu aspek penting dalam pembelajaran (instruksional). Proses instruksional dibangun berdasarkan strategi instruksional, strategi tersebut berbentuk sintesis dari langkah-langkah kegiatan instruksional, metode, media dan alat, dan waktu yang diperlukan untuk menyajikan bahan instruksioanal (instructional content) ke arah pencapaian tujuan.

Menurut Susilana (Susilana, Rudi, and Riyana 2007) "Modul interaktif merupakan alat atau sarana pembelajaran yang berisi materi, metode, batasan-batasan, dan cara mengevaluasi yang dirancang secara sistematis dan menarik untuk mencapai kompetensi/subkompetensi mata kuliah yang diharapkan sesuai dengan tingkat kompleksitasnya". Pengembangan media pembelajaran modul interaktif ini sendiri termasuk salah satu aplikasi kawasan teknologi pendidikan (TP), yaitu dalam kawasan desain dan kawasan pengembangan.

Menurut Seels \& Riche dalam (Warsita 2008) Warsita "Kawasan pengembangan mencakup fungsi-fungsi desain, produksi, dan penyapaian, maka suatu bahan dapat di desain dengan menggunakan satujenis teknologi, diproduksi dengan menggunakan yang lain, dan disampaikan dengan menggunakan yang lain lagi". Di dalam kawasan pengembangan terdapat keterkaitan yang kompleks antara teknologi dan teori yang mendorong baik dari segi desain, pesan maupun strategi pembelajaran, yang bertujuan untuk merancang sebuah sistem pembelajaran dan pengembangannya kedalam sistem pembelajaran dan harapannya nanti hasil dari desain dan pengembangan suatu sistem 
dapat dimanfaatkan atau dipergunakan dalam sistem pembelajaran.

\section{METODE PENELITIAN}

Penelitian ini merupakan penelitian pengembangan research and development (R\&D) yang mengadaptasi model pengembangan ADDIE (Analysis, Design, Development, Implementation, Evaluation) (Branch 2009). Penelitian ini bertujuan untuk mengembangkan produk pembelajaran yang akan digunakan di sekolah. Penelitian pengembangan adalah penelitian yang memfokuskan pada pengembangan produk, baik produk industri maupun produk pembelajaran dalam dunia sekolah yang diuji secara sistematis di lapangan, dievaluasi, dan disempurnakan hingga memenuhi kriteria efektif, dan bermutu sehingga layak untuk digunakan. Menurut (Putra 2013) penelitian dan pengembangan adalah suatu metode penelitian yang secara sengaja, sistematis, bertujuan/diarahkan untuk mencari, menemukan, merumuskan, memperbaiki, mengembangkan, menghasilkan, menguji efektifan produk model, metode, strategi/cara, jasa prosedur tertentu yang lebih unggul, baru efektif, efisien, produktif, dan bermakna.

Penelitian ini bertujuan untuk mengembangkan produk modul elektronik untuk tema ekosistem kelas V SDN 2 Sindangsari Kecamatan Leuwigoong Kabupaten Garut.

Model ADDIE terdiri dari 5 tahap, yaitu tahap Analisis, Desain, Pengembangan, Implementasi, dan Evaluasi, sebagai berikut :

1)Tahap analisis merupakan tahapan pertama sebelum mengembangkan produk. Pada tahap ini kebutuhan dan tujuan dari pembelajaran dianalisis terhadap apa yang akan dipelajari oleh siswa. 2) Tahap desain terdiri dari penyusunan isi modul elektronik seperti materi, cerita, prakarya dan penyusunan instrumen. 3) Pada tahap pengembangan dikembangkan bahan ajar berupa modul elektronik berbasis Sigil. 4) Setelah tahap pengembangan dilakukan implementasi yang diuji cobakan kepada siswa kelas 5 sekolah dasar SDN 2 Sindangsari Leuwigoong. 5) Tahap terakhir yaitu tahap evaluasi, tahap ini dilakukan dengan melakukan uji kelayakan modul elektronik berbasis Sigil.
Dalam pengumpulan data ini melibatkan dua pendekatan untuk menelaah risetnya yaitu kuantitatif dan kualitatif (Darmawan 2019). Riset kuantitatif pada penelitian ini ketika dilakukan pengujian efektivitas dari produk yang dikembangkan. Pengujian efektivitas melibatkan statistik. Adapun riset kualitatif diperoleh data pada saat mengembangkan produk berupa modul elektrponik. Pada penelitian ini, terdapat validitas konten yang dilakukan melalui konsultasi dengan para ahli (Kriteria validasi Penilaian Pakar) sesuai dengan bidangnya. Uji validitas dalam penelitian ini melibatkan ahli media. Pengumpulan data pada penelitian ini dilakukan dengan melakukan validasi ahli untuk melihat apakah e-modul layak digunakan atau tidak. Pengumpulan data dalam penelitian ini juga dilakukan dengan menggunakan angket yaitu daftar pertanyaan yang diberikan kepada orang yang memiliki relevansi memberikan pendapat terhadap produk.

\section{HASIL DAN PEMBAHASAN}

Penyusunan

program pengembangan media pembelajaran dimulai dari tahap perencanaan yaitu untuk merumuskan tujuan khusus yang ingin dicapai dalam pengembangan modul elektronik. Selanjutnya peneliti menyiapkan dan mengumpulkan materi atau bahan pelajaran yang akan dikembangkan berdasarkan satuan kegiatan di SDN 2 Sindangsari Leuwigoong. Setelah materi disusun dan direncanakan dengan matang, kemudian dibuat rancangan desain media pembelajaran.

Penelitian ini merupakan penelitian pengembangan yang menghasilkan bahan ajar berupa modul elektronik tema ekosistem. Prosedur pengembangan dimulai dengan analisis kebutuhan terlebih dahulu. Pada tahap ini kebutuhan dan tujuan dari pembelajaran dianalisis terhadap apa yang akan dipelajari oleh siswa berdasarkan hasil yang ada dilapangan khususnya kelas V SD guru. Diperlukan bahan ajar yang uraian materinya sudah berkaitan dengan tema ekosistem .

Tahap desain terdiri dari penyusunan isi modul elektronik seperti materi, cerita, prakarya dan penyusunan instrumen. Tahap ini dilakukan dengan mengaitkan materi, cerita dan prakarya 
dengan tema ekosistem. Pada tahap pengembangan, desain yang sudah disusun dikembangkan menjadi sebuah produk berupa bahan ajar dalam bentuk modul elektronik tema ekosistem yang dalam penggunaannya berbasis Sigil. Setelah selesai dilakukan pengembangan, peneliti melakukan validasi oleh ahli yang berkompeten di bidangnya, hasilnya dapat dilihat pada tabel 1 berikut:

Tabel 3. Hasil validasi ahli

\begin{tabular}{|l|l|l|l|}
\hline No & Aspek & $\begin{array}{l}\text { Tingkat } \\
\text { Kelayakan }\end{array}$ & Kategori \\
\hline 1 & Materi & 84,2 & Sangat layak \\
\hline 2 & Media & 85,3 & Sangat layak \\
\hline 3 & Bahasa & 86,6 & Sangat layak \\
\hline
\end{tabular}

Berdasarkan tabel 3. Hasil validasi dari ahli menunjukkan bahwa pada aspek materi sebesar 84,2 berarti termasuk dalam kategori Sangat Layak, aspek media sebesar 85,3, termasuk kategori Sangat Layak, dan aspek bahasa sebesar 86,6 termasuk kategori Sangat Layak. Berdasarkan hasil validasi yang dilakukan, dapat disimpulkan bahwa e-module layak untuk dikembangkan dan diuji. Komponen e-modul meliputi judul/halaman sampul, kompetensi inti, kompetensi dasar, tujuan pembelajaran, cerita tentang ekosistem, pertanyaan, uraian materi, evaluasi.

Tahap implementasi diuji cobakan kepada siswa kelas 5 sekolah dasar untuk mengetahui hasil belajar siswa. Setelah modul selesai dikembangkan, modul elektronik diujicobakan kepada siswa kelas VA SDN 2 sindangsari Leuwigoong sebagai bahan ajar dalam kegiatan pembelajaran yang berlangsung selama 2x45 menit. Sebelum kegiatan pembelajaran berlangsung, siswa kelas VA dibagi menjadi 5 kelompok kecil dengan jumlah siswa setiap kelompok 5-6 orang siswa. Setelah pelaksanaan uji coba selesai, siswa diminta untuk mengisi tes dan angket respon terhadap penggunaan modul elektronik dalam proses pembelajaran.

Hasil data persepsi yang didapatkan dari siswa dengan menggunakan angket persepsi pada penggunaan modul elektronik dalam kegiatan pembelajaran dapat dilihat pada hasil berikut ini:

Berdasarkan hasil deskripsi statistik persepsi siwa pada penggunaan modul elektronik menunjukkan bahwa skor angka yang diperoleh dari 28 responden menghasilkan data yang valid dengan rata-rata 57.5 , median 60 , modus 65 , dengan nilai minimum 55 dan nilai maksimunnya 67. Untuk menunjukkan hasil dari respon siswa yang termasuk dalam kategori sangat baik, baik, cukup, tidak baik, dan sangat tidak baik, maka dapat dilihat pada tabel berdasarkan interval skor. Data yang diperoleh 28 responden menunjukkan hasil persepsi termasuk dalam kategori cukup dengan frekuensi 28 siswa dan persentase sebesar $100 \%$. Dilihat dari data yang dihasilkan angket persepsi menunjukkan bahwa terdapat respon positif dari siswa dalam kategori cukup. Jadi dengan menggunakan e-modul, ini membantu guru untuk membangun persepsi siswa dalam belajar.

\section{KESIMPULAN}

Penelitian ini menghasilkan bahan ajar berupa modul elektronik yang telah di uji coba oleh parah ahli dan sangat layak digunakan dan memiliki daya tarik bagi siswa. Berdasarkan hasil penelitian yang telah dilakukan, dapat dilihat bahwa siswa memiliki respon dan hasil belajar yang baik setelah diperkenalkan e-modul tema ekosistem di dalam pembelajaran.

\section{DAFTAR PUSTAKA}

Branch, Robert Maribe. 2009. Instructional Design: The ADDIE Approac. New York: Springer USA.

Darmawan, Deni. 2014. Teknologi Pembelajaran. Bandung: Alfabeta.

2019. Metode Penelitian Kuantitatif. Bandung: Rosda.

Putra, Nusa. 2013. Research and Devolopment: Penelitian Dan Pengembangan. Jakarta: Rajawali Press.

Sagala. S. 2008. Konsep Dan Makna Pembelajaran. Bandung: Alfabeta.

Sukirno, and Syamsuriyanti. 2018. "Faktor Determinan Profesionalisme Guru."” Jurnal Kependidikan 2(1).

Surya, Mohammad. 2004. Psikologi Pembelajaran Dan Pengajaran. Bandung: Bani Quraisy.

Susilana, Rudi, and Cepi Riyana. 2007. Media Pembelajaran. Bandung: Wacana 
Jurnal IImiah Mandala Education

Vol. 7 No. 1. Januari 2021

http://ejournal.mandalanursa.org/index.php/JIME/index

terakreditasi Peringkat 4 (No. SK: 36/E/KPT/2019)

Prima.

Warsita, B. 2008. Dasar-Dasar Teknologi

Pembelajaran. Jakarta: Rineka Cipta. 